\title{
I'll Be Your First Mate: Art, Advocacy and the Assuming White "I"1
}

\section{Daniella Trimboli ${ }^{2}$}

This essay explores the implications of white allyship and activism within the context of refugee advocay in Australia. The Melbournebased organisation I'll Be your First Mate (IBYFM), set up by the author and collaborators as a space to challenge dominant harmful discourse about refugees through art, initiated an honest and selfcritical engagement with different forms of activism. The essay interrogates the potential complicity of well-intentioned allies in upholding discriminatory structures through white managerialism, the successes of truly collaborative engagement between white citizen allies and refugees and asylum seekers, and the power of art to create spaces of conversation. [Article copies available for a fee from The Transformative Studies Institute. E-mail address: journal@transformativestudies.org Website: http://www.transformativestudies.org 02020 by The Transformative Studies Institute. All rights reserved.]

KEYWORDS: Asylum Seekers, Refugees, Australia, Activism, Whiteness, Community Arts, Digital Arts.

I'll Be Your First Mate (IBYFM) started in Melbourne in 2014 with the aim of creating an alternative space for the reinterpretation of asylum seeker rhetoric. Conceptualised by visual artist Ry Wilkin, politics Ph.D. candidate Tia Di Biase and me, Daniella Trimboli, a (then) cultural studies Ph.D. candidate, the collaborative organisation sought to create an artistic space where people could creatively rethink dominant understandings of asylum seekers, refugees, and migration.

We were deeply concerned about the way refugees had (once again) been used as political pawns in Australian political campaigns, with both

\footnotetext{
${ }^{1}$ An earlier version of this article was published on www.thepin.org: Trimboli, Daniella. "I'll Be Your First Mate: Whiteness and the Pursuit of Good Feeling." THE PIN, 10 Feb. 2018, http://www.thepin.org/think/daniella-trimboli.

${ }^{2}$ Daniella Trimboli, Ph.D., is a postdoctoral research fellow at the Alfred Deakin Institute for Citizenship and Globalistion, Deakin University and co-founder of I'll Be Your First Mate. Address correspondence to: Dr. Daniella Trimboli, ADI, Level 6, Building C, Deakin University, 221 Burwood Highway, Burwood, VIC 3125, Australia; e-mail: daniella.trimboli@deakin.edu.au.
} 


\section{Daniella Trimboli}

major political parties emphasising border protection from asylum seekers arriving by boat in the 2013 Federal election. We wanted to respond to this political distortion, but we didn't know how. What we did know was that art seemed like the best place to start. We felt art could allow the conversation to be opened up in a more dynamic way, that it would help us to interrogate representations of asylum seeking, including our own re-presentations. This latter element was particularly important since we were three non-refugees.

We decided to set-up an online arts space that would share artistic explorations-visual, written, moving image - on the topic of asylum seeking and migration. We put out an open call for artistic submissions and gave all visual submissions the option of being simultaneously uploaded to a Red Bubble ${ }^{3}$ site we also managed. The public could then purchase artwork directly from the site, and any money we raised from these sales would go directly to the Melbourne-based Asylum Seeker Resource Centre - one of the most significant refugee funding and advocacy bodies in Australia.

Meanwhile, Ry set about making art of his own that could be used by IBYFM in a range of ways - including stencil posters, which we pastedup throughout the streets of Melbourne. As we began to receive more written submissions, for example, poetry, Ry started collaborating with the writers to produce hybrid visual-written artworks, which could then be submitted to Red Bubble for further fundraising.

Finally, the project began to recruit local Melbourne businesses who would support the IBYFM ethos, in particular by putting an IBYFM sticker on their door or window. We hoped the stickers would act as small signs of solidarity, and also visually symbolise that the business was a safe space of migrants and refugees.

The project began humbly - two Ph.D. candidates and one visual artist feeling frustrated by the ironically immobilising political debate about the phenomenon of global mobility. Two years and a substantial hiatus later, we are clearer about what it is that we want the project to be and where we'd like it to go. As we consolidate our aims and outcomes, we become aware of the need to more clearly position the project. In particular, the need to explore the question: Who is the 'I' who says 'I'll be your first mate'? The hermeneutics of this statement undoubtedly implicates the project within a certain structure of race politics, a point we have been aware of since the project's inception. From the onset, we

\footnotetext{
${ }^{3}$ Red Bubble is an online marketplace where independent artists can upload artwork for sale in various forms, e.g. prints on canvas, posters, greeting cards, ceramics, clothing, etc. A portion of the sales is returned to the artists directly.
} 
have been conscious of the ways in which whiteness infiltrates public art and human rights interventions, even when the intentions of these interventions are affirmative. This article considers how whiteness can haunt advocacy work for asylum seekers, including our own work.

\section{FROM APATHY TO ACTION}

Ry, Tia, and I developed IBYFM in response to a mutual concern that we were each falling into a pit of political apathy. Like many Australians, we were overwhelmed by the newly elected Abbott Government's relentlessly grotesque treatment of asylum seekers. A main throng of his political campaign was to extend what had already become, via the previous Labor party's legislation, the most severe asylum seeker and refugee policies ever seen in Australia. These policies included navy interception of all boats, offshore 'processing', and no chance of Australian settlement for any refugee arriving by boat. (It is worthwhile noting that many of the asylum seekers who were intercepted by boat and sent to offshore detention centres on in 2013 and 2014 continue to remain imprisoned to this day, despite being proven to be refugees.) We rationed our intakes of news and political commentary on the topic, inevitably switching off altogether. We ritualised this performance, spinning ourselves into internal rages that rendered us silent. It was hardly a novel experience. When we spoke to others we realised they were doing the same dance - any mention of "Abbott's Australia" and the treatment of refugees and they would quietly shake their heads, bewildered.

Essentially, we were being shocked into submission. We knew we had to do something differently if we were to remain attached politically and ensure that this Abbott guy would not get away with such folly-but what? At first, we toyed with the idea of inverting the exaggerated discourse on asylum seeker boats into a pro-asylum seeker stance with art. Imagery and language used by Abbott and the dominant media in Australia frequently incited the historic, racialised notion of (white) Australia as being a country at risk of being 'flooded' by dangerous ethnic Others, in this instance by 'Muslims', who, due to rising Islamophobia in Australia, quickly became associated with 'terrorists'. Asylum seeker boats were semiotically attached to the idea of threat that arrives by sea - in 'waves' - and needed to be stopped at all costs. 'Stop the Boats' thus became a slogan for the Abbott Liberal Party, with boats becoming synonymous with border invasion. 


\section{Daniella Trimboli}

Ry's visual art practice has a flair for illustration, animation, and street art. Since the word 'boats' saturated political discourse, we asked, what would happen if we took 'boats' to its exaggerated limits artistically? We considered stencilling boats, all sorts of boats - fishing boats, row boats, cruise ship boats, asylum seeker boats, cargo boats - as far and wide as possible on the streets of Melbourne, alongside the slogan: We Heart Boats. This approach would begin with the same strategy of exaggeration being deployed by the government, then invert it. Ry made our first stencil-a hybrid boat formed from many types of boats-and we prepared to hit the streets, but not before our doubts surfaced.

'Is it really appropriate to say that we heart boats, even if to make a point?'

'What if people miss the point?'

'Will people think we are making light of a very dire situation?'

'Are we making light of a very dire situation?'

We decided to pause to bolster the vision of the project. The three of us agreed on four things about the contemporary asylum seeker rhetoric, and it was these four things that we targeted. First, many Australians were not getting accurate information about asylum seekers and refugees. The persistent use of simplistic slogans like 'stop the boats' and 'queue jumpers,' in combination with the strategic shutdown of legitimate information sites about asylum seeker arrivals, was exacerbating the long-held misconceptions about refugees in this country. Common misunderstandings included such things as: seeking asylum by boat is illegal, there are refugee waiting queues, and, Australian refugees receive more welfare than 'ordinary Australians' in need.

Second, the means of presenting accurate information on the topic was often ineffective, if not problematic, in getting across to the ordinary Australian. Shock strategies were frequently used by advocacy groups to convey statistics about the hardships of asylum seekers. Australians had been long aware that conditions in detention centres are terrible and that the experience of seeking asylum by boat is traumatic for families. This knowledge seemed to have done relatively little to change attitudes about asylum seekers in Australia. Tia's background in psychology helped explain this apparent immunity:often, shock campaigns result in the receiver disconnecting from the message as a means to prevent adverse feelings of anxiety and guilt. Additionally, these kinds of appeals bordered on the exploitative at times, the refugee person becoming a trope for pity, powerlessness, and non-identity.

Third, conventional advocacy tended to create obvious distinctions between the political left and right. As Tia further explained, research 
has demonstrated that presenting facts from one side of the debate or the other can have the opposite effect by strengthening beliefs of those with strong attitudes in opposition to the message. These divisive ideological strategies served to muddy the refugee debate even further, or turn away people who might otherwise connect with the conversation simply because of their broader political alignments.

Fourth, and finally, we felt that many people who did want to do something to contribute to the asylum seeker cause were either unsure how to help, or were uncomfortable with conventional forms of advocacy, such as street protest. While we understood the reasoning behind these advocacy strategies, we felt that they often missed the nuanced aspects associated with forced migration and also isolated many people from the conversation.

Points three and four were made clear to me in 2011 when I attended a lunchtime meeting held by The University of Melbourne's arm of the Refugee Action Collective (RAC). It was an information meeting, designed to outline RAC's main aims and hopefully recruit some new members. I was keen to get involved and thus arrived a little early. Within moments of sitting in the meeting room I was given material on the Socialist Alliance and a representative began to question me about my political engagement, in particular, my alliance or otherwise as a Marxist. I am a cultural studies scholar, I have studied Marxist theory and redefined my own cultural politics through Marx's work and that of his successors; however, I felt daunted by what became a rather antagonistic conversation. Those around me who were also inevitably interrogated, seemed even more hijacked by the questioning. I think it's fair to say we were relieved when the official meeting got underway.

A few talks followed about refugee policy in Australia, the reasons why members of RAC had joined, and the overall aims of RAC and the Socialist Alliance. The final part of the meeting was a screening showing the protests that happened at Woomera Detention Centre in South Australia's Far North in 2007. As a former South Australian resident, I was familiar with the protests and had supported them passionately at the time. Over an Easter long weekend, the protesters had camped in front of the centre, and eventually helped some detainees get free of the fence. The detainees were quickly returned by police and security officers and many protesters were arrested. The short film documenting this intervention was certainly interesting, but it was highly emotive and distressing and, for many people, would be considered an example of extreme action. At the end of the screening, some RAC facilitators suggested that we attempt to re-enact the intervention here in Melbourne 


\section{Daniella Trimboli}

and Victoria. Several people in the room got up and sheepishly shuffled out.

I felt disappointed by the meeting. While I understand the intentions and passion of this type of recruitment, I worry about its potential isolating outcome. All political organisations have the right to petition their platform, but I couldn't help but feel that doing so in this way, at this casual, meet and greet event, lost more for the organisation's refugee advocacy than it gained. There were many people in the room who wanted to be a part of the change, who wanted to find out more about asylum seekers and contribute to a refugee rights' movement. However, they were turned off, seemingly because their broader political aims, approaches, and general day-to-day lives did not resonate with certain leftist ideologies or activist approaches.

Saturating civil rights initiatives with strong left or right ideologies seems to further limit the small space reserved for political conversation. This is troubling considering that a common sentiment expressed by Australians at election time is frustration about being misled by the media and let down by politicians commonly perceived to be 'all the same' ilk. In short: Australians express a desire to genuinely participate and be heard. Reflecting on this, Ry, Tia, and I felt that many of the movements designed to petition for asylum seeker rights closed the conversation to many people who would otherwise be interested in thoughtfully engaging with it. These kinds of approaches ultimately work to the binary positions of us-versus-them by engaging in divisive, rather than inclusive, conversations.

We thus believed that any intervention we made had to look and feel different to the common interventions being made about refugees. We wanted our project to open up the discussion and cultivate, or at least allow for, fragmentation. It seemed crucial to create an independent site where all people concerned about the treatment of asylum seekers could gather, regardless of their broader political alliances. For that reason, IBYFM is not principally aligned with any political organisation or ideology, although it does support the work of many advocacy organisations.

The second point was the need to think about the nuanced aspects of refugees and migrants at large. How do we explore the everyday aspects of migration that do not get space in the public imagination and how do we do so in a genuine way that neither makes light of refugee life nor exploits it? 


\section{WHITENESS AND THE PURSUIT OF GOOD FEELING}

Good-will moves organisations like IBYFM and underlies multiculturalism at large. But what are the terms of this good-will? In his seminal project on Australian multiculturalism, White Nation (1998), anthropologist Ghassan Hage argues that the needs-based model of multiculturalism was replaced by a white middle-class cosmopolitanism that positioned cultural diversity as a commodity for elitist consumption. $\mathrm{He}$ claims that "tolerant Australians" fighting for "good multiculturalism" may have the best intentions, but in fact there is no such thing as tolerant and intolerant practices: both perpetuate the same racist underpinnings (93). 'Those who execute [tolerant practices], "good" as they are, share and inhabit along with White "evil" nationalists the same imaginary position of power within a nation imagined as "theirs"... [T] hey enact the same White national fantasy' (79). In this sense, those fighting the cause of liberal multiculturalism cannot be easily distinguished from those that Hage terms 'Hansonites,' or other white Australians with overtly racist attitudes. Hage recognises that people like Pauline Hanson ${ }^{4}$ and many of her supporters really believe they are not racist. Combining an approach of ethical reflexivity and a critique of inconspicuous deployments, Hage not only considers how nationalist practices embed these ideas but, importantly, how they incorporate the ideas of those he finds less racist. Namely, what are the conditions that constitute these supposed "more or less" levels of racism? Similarly, anthropologist and cultural theorist Elizabeth Povinelli (2002) suggests that instead of writing Hanson off as racist because her ideas seem repellent, we should, in fact, ponder them seriously (52). Even if to critically refute these notions. Both Hage and Povinelli are here pointing to the importance of what cultural theorist Sneja Gunew (2004) calls the 'shifty work' of multiculturalism, and our need to be persistently critical of it.

In other words, we need to carefully consider what work gets done in the name of multiculturalism and cultural inclusion - a point that can be explained by something I witnessed while at a refugee rally in 2013 . The rally was organised by the Refugee Action Collective and was supported by a number of asylum seeker advocacy groups, such as the excellent and tirelessly hard-working Asylum Seeker Resource Centre. In spite of all the doubts one could raise regarding the effectiveness of such rallies, I

\footnotetext{
${ }^{4}$ Pauline Hanson is a conservative Australian politician and personality known for her anti-immigrant ideas and platforms. She was the founder and original leader of the rightwing, anti-multiculturalism political party One Nation.
} 


\section{Daniella Trimboli}

support them as much as I can, because I do believe that people-presence on the streets is an important aspect of political campaigning. It is not so much whether or not the politicians care or even notice the gathering that drives my desire to attend rallies, but how it effects ordinary folk on the streets, including myself.

I like to observe the expressions of the faces in the windows of trams, unable to move due to the flood of feet on the tram tracks; to smile extra big at the angry tram driver when he yells at us to 'get a job'; to see the look of confusion and curiosity from shoppers walking out of stores on Bourke Street Mall, Melbourne's main shopping strip. I like to imagine how these people are interpreting the scene. I figure that even those who are perturbed by the disturbance still have to reflect on the issue-and reflection is always a good thing. Maybe, every now and then, this reflection results in someone seeking out more information, asking more questions, changing their minds, or even quietly applauding. This possibility fuels my participation.

Finding these sites of togetherness and motivation seems all the more important to me as time goes on, and as conditions of asylum seekers and refugees grows increasingly dismal. When I stand in a crowd of people taking a stand on the issue my hope for Australia and people at large is reignited, I am reminded of the compassion within our country and extraordinary people who need our support. I leave more determined to continue campaigning for refugee rights. In short: participation in street protest makes me feel good.

The desire to feel good does not, at first glance, seem like a problematic pursuit, however, an incident at this particular rally helps to illuminate the dangers inherent in the chase of good feeling. I was standing on the stairs of the State Library, amidst a crowd of hundreds gathered in front of a makeshift stage to listen to the organised speeches. A Tamil refugee came to the stand to address us. Despite there being a PA and accompanying speakers, it was difficult to hear him speak. This difficulty was, in part, due to the quality of the sound system in use, and also due to the speaker having to talk in a second language, namely, English. Nonetheless, it most certainly would have been possible for me to hear the speaker had it not been for the small group of people chatting amongst themselves in what was a flippant yet violent disregard of this man's voice. Donned in Greens Party t-shirts, they discussed the Labor leadership takeover. Discerning glances from a few people surrounding them did nothing to cease their passionate points. What did cease their conversation was the change of speaker-when the refugee speaker stepped aside and Greens Leader Adam Bandt stepped forward, the 
group fell quiet. At the end of Bandt's speech, the group applauded and cheered loudly, commenting on Bandt's fantastic leadership and humanity.

What just happened here? These people-well-meaning, passionate, and clearly driven to defend the rights of marginalised Others-just silenced the community they were here to give voice to. They listened attentively when (white, 'non-accented'-English speaking) Adam Bandt spoke about refugee rights, but talked over a refugee actually in need of the rights. Their actions were obliviously carried out, but they hit the heart of the race politics issue here in Australia that Hage and others have traced. Namely, as the long-time managers of the national space, white Australians too easily forget their position of power, as well as their complicity in maintaining it. They choose when to listen and when to ignore.

In this neo-colonial context, projects like IBYFM emerge easily enough because they come from the white national space. The obvious problem, of course, is that in standing in the centre and offering those on the margins an invitation to join us here, the unequal and racialised power structure is maintained. The refugee is bestowed friendship, tolerance, and good will, in such a way that they cannot survive on her own terms. In this structure, the refugee remains at the mercy of the white manager.

Hage's (2014) comments on the online campaign \#illridewithyou further explain this situation. The \#illridewithyou campaign was instigated on 15 December 2014, following the siege of a Sydney café by a man who brandished a flag with the shahādah creed printed on it, suggesting an association with Islam. Several people were held in the café as hostages; two of them eventually killed by police gunfire. The incident was immediately regarded as an act of Islamic terrorism, despite this being disproved soon afterwards. Following the event, a Sydney woman, Rachel Jacobs, tweeted about seeing a young Muslim woman taking her head covering off on a train. When they disembarked, Jacobs ran after her and said: 'put it back on. I'll walk with u.' Her tweet instigated a fellow Tweeter "Sir Tessa" to tweet: 'If you reg take the bus b/w Coogee/Martin PL, wear religious attire, \& don't feel safe alone: I'll ride with you. @me for schedule.' The hashtag \#illridewithyou was born: twitter and facebook users began tweeting their public transport routes, offering to ride alongside Muslim Australians who felt threatened by non-Muslim Australians. On his social media page, Hage compares the campaign with an old French anti-racist slogan and movement: "'touche pas a mon pote" (don't touch my mate) of SOS racisme.' He argues that 


\section{Daniella Trimboli}

these kinds of projects are important in so far as they act as 'transitional anti-racist movement[s]':

That is, ultimately, the racialised don't want to be dependent on the good will of others to feel safe. This is not to rob the people engaging in it of any of the value of their good will and the nobility of their intentions. What's more relations of protection can develop into egalitarian relations of friendship and more. But they can also reproduce themselves into relations of protection. (Profile Page)

\section{DETANGLING RELATIONS OF PROTECTION}

When we approach IBYFM in this critical lens, it feels as if we have backed it into a corner. If IBYFM enters territory of white managerialism, should we cease the project? We have deliberated on this question many times, but we have decided that, for now, the answer is no. The answer seems to lie, instead, in figuring out ways to disrupt the territory of white managerialism that the project draws on. Or, following literary and postcolonialism theorist Gayatri Spivak's suggestion, to acknowledge that the structure of racialisation is so pervasive that it has the ability to corner even those in a position of power, to lead them to a dead-end where they decide to give up. In an interview with Gunew about speaking "in the name of" migrant Others, Spivak (1990) explains:

I will have in an undergraduate class, let's say, a young, white male student, politically-correct, who will say: "I am only a bourgeois white male, I can't speak." [...] I say to them: "Why not develop a certain degree of rage against the history that has written such an abject script for you that you are silenced?" Then you begin to investigate what it is that silences you, rather than take this very deterministic position - since my skin colour is this, since my sex is this, I cannot speak. (62)

Spivak (1990) adds that while it is always a risk to speak about the ethnic Other, the alternative, namely, to avoid critique, 'is salving your conscience, and allowing you not to do any homework' (63). IBFYM is committed to doing its homework, to the task of learning 'what is going on [...] through language, through specific programmes of study, but also at the same time through a historical critique of [our] position as the investigating person[s]' (Spivak 63). We hope this commitment allows us to add to the discourse of refugees and asylum seekers in a way that is 
constantly self-reflexive. More importantly, we hope it allows IBYFM to be a point of entry into a much wider conversation that becomes increasingly fragmented and opened up by non-white voices, perspectives, and criticisms. Juliana Qian (2014) illuminates this strategy in her incisive response to Elizabeth O'Shea in an Overland debate on privilege. Qian argues that tools are required to rethink the commonplace binary constructed within activism between 'advocates and adversaries,' tools that enable the competing philosophies and political tactics within advocacy to surface.

In a comment about \#illridewithyou, Hage (Profile Page) summarises the need for advocacy campaigns to be a starting- rather than an endpoint:

But now we have to ask: is this where we want to end? A society where there are lots of people willing to protect Muslims and where Muslims need to be protected? I would argue: of course we don't. We want to move those who have struggled to protect Muslims to move on and continue to struggle to achieve a society where Muslims don't need to be protected. That's the point of critique. It is about pushing such a good movement further not about stopping it in its tracks.

\section{CONCLUSION: WHAT'S IN A NAME?}

We were being quite tactical when we named the project I'll Be Your First Mate-playing on words associated with seafaring and also trying to re-deploy the notion of Australian "mateship" in a tongue-in-cheek manner. Our task as facilitators of this project is to now try and push its advocacy beyond the structure of white paternalism; essentially, to pull apart, invert, and dissect the statement: 'I'll Be Your First Mate.' We still have a long way to go, but, looking ahead, our aim is to make the 'I' featured in the statement 'I'll Be Your First Mate' a very slippery subject, an 'I' that is difficult to locate. By accepting a range of different art forms from a range of different people, we hope that the 'I' is opened up: at any one moment the 'I' might be the refugee, the so-called boat person, the white refugee detention centre worker, the volunteer lawyer, the nonAnglo migrant community, the gallery space, the young LebaneseAustralian girl in school.

The word 'first' implies essence, origins and cultural authority-and we know the many and troubled connotations of 'mate.' But we pushed on with the name I'll Be Your First Mate because we wanted to keep 


\section{Daniella Trimboli}

alive the attachment to boats and to the oceans that, despite their incredible vastness and increasingly active patrols, are crossed persistently by people in search of survival. The first mate on a boat is not the captain, or the person in charge. The first mate is the person that uses their relative authority to support the captain, or the skipper. The first mate is actually second-in-charge.

\section{POSTCRIPT, 2019}

In 2017, IBYFM went into hiatus, partly because we had become incredibly time-poor and partly because we knew we could not move forward with the project at this point without deep collaboration with refugees. During the three years IBYFM operated, we developed an excellent allyship with the Sydney-based organisation Refugee Art Project, cross-promoting each other's work and often sharing artwork for publication. We wanted to increase these kinds of collaborative spaces, but simply did not have the time or financial resources needed to do so. By this time, the excellent organisation RISE had also formed in Australia, allowing refugee advocacy to be run by those directly affected by refugee discourse and policies, namely: refugees.

IBYFM made a small reappearance in late 2012 when the Australian Liberal Party announced it would be shutting down the Manus Island detention centre. The decision gave asylum seekers in detention who were proven to be 'genuine refugees' only one option: to be resettled on mainalnd Papua New Guinea (PNG) via a political deal made between the two nation's respective leaders. All others would go into other detention facilities on PNG. The conditions for resettlement were deeply troubling, and led many asylum seekers to panic and eventually peacefully protest by refusing food. These protests were met with severe violence by detention security, which the Australian public became aware of due to some of the refugees having phones and sending updates to people in Australia. As journalists were barred from going to the detention centre, these updates became the only way for information about the treatment of those in the Centre to be shared with the Australian public. Mobile phone data top-ups for those refugees with phones thus became a crucial need. IBYFM resurfaced to raise money for these top-ups, using an illustration donated by Safdar Ahmed of Refugee Art Project as the focal point, but also contacting all previous IBYFM supporters and artists for monetary donations. We had access to a confidential list of phone numbers of people in detention, including their names, and were able to directly top-up hundreds of dollars worth 
of mobile phones. These actions were small overall, but the capacity for art, technology, and fundraising to interconnect political resistance and solidarity was significant. Perhaps one day in the future IBYFM can return in another iteration, in which this capacity is more greatly reached. Time will tell.

\section{WORKS CITED}

Hage, Ghassan. White Nation: Fantasies of White Supremacy in a Multicultural Society. Pluto Press, 1998. https://doi.org/10.1017/s1321816600001161

Profile Page, Facebook, 16 October 2014,
https://www.facebook.com/ghahagea. Accessed 14 October 2015.

Povinelli, Elizabeth. The Cunning of Recognition: Indigenous Alterities and the Making of Australian Multiculturalism. Duke University Press, 2002.

Qian, Juliana. (2014). Should the Left Check its Privilege? A Debate between Elizabeth O'Shea and Juliana Qian. Overland, no. 215, 2014, pp. 15-23.

Spivak, Gayatri and Sneja Gunew. Questions of Multi-Culturalism. The Post-Colonial Critic: Interviews, Strategies, Dialogues: Gayatri Chakravorty Spivak, edited by Sarah Harasym, Routledge, 1990, pp. 59-66. https://doi.org/10.2307/3730807 